\title{
O sertão de costas para a Reforma Educacional do Ceará: Juazeiro do Norte não
}

\section{responde ao Cadastro Escolar}

The back of the coast for the Educational Reform of Ceará: Juazeiro do Norte does not respond to the School Register

La parte trasera de la costa para la Reforma Educativa de Ceará: Juazeiro do Norte no responde al Registro Escolar

Recebido: 04/05/2021 | Revisado: 09/05/2021 | Aceito: 11/05/2021 | Publicado: 28/05/2021

Francisco Ari de Andrade

ORCID: https://orcid.org/0000-0002-3028-9867 Universidade Federal do Ceará, Brasil

E-mail: andrade.ari7@gmail.com

\begin{abstract}
Resumo
Essa pesquisa é de cunho qualitativa, de natureza bibliográfica, com enfoque na prática da pesquisa em história da educação, conforme as orientações sugeridas por Luca (2020). Tem por ponto de partida um embate ocorrido no percurso da reforma escolar cearense, no início da década de 1920, envolvendo o educador Lourenço Filho (1897-1970 e o Padre Cícero Romão (1844-1934). A querela se inicia quando o sacerdote não responde o Cadastro Escolar. O desenvolvimento desse estudo foi feito em duas etapas. Na primeira, realizou-se a leitura analítica da obra Juazeiro do Padre Cícero (2002), de autoria do referido educador paulista, tomando-se como ponto de análise um comentário contido na página 12 do prefácio feito pelo pesquisador Carlos Monarcha, da UNESP, acerca da resistência do padre, emperrando o andamento da reforma cearense. As questões suscitadas pela leitura, dando conta dos aspectos culturais e sociais da realidade sertaneja, foram cruzadas com outras leituras, dando-se início à segunda etapa. O cruzamento de tais leituras, permitiu um mapeamento e um delineamento do território histórico onde se travou aquele duelo ideológico, em um contexto cultural dicotômico: urbano versus rural. Admite-se que a ampliação do entendimento dessa questão, à luz do conjunto das leituras apropriadas, seja oportuna para refletir o projeto de reforma do ensino primário, cuja escola pública devia ter sido ofertada às massas, naquele cenário histórico da educação cearense, acima dos interesses e das convicções ideológica e religiosas.
\end{abstract}

Palavras-chave: Educação; Reforma; Resistência; Cadastro escolar.

\begin{abstract}
This research is of a qualitative nature, of a bibliographic nature, with a focus on the practice of research in the history of education, according to the guidelines suggested by Luca (2020). The starting point is a clash that occurred in the course of the Ceará school reform, in the beginning of the 1920s, involving the educator Lourenço Filho (1897-1970 and Father Cícero Romão (1844-1934). responds to the School Register The development of this study was done in two stages: in the first, the analytical reading of the work Juazeiro do Padre Cícero (2002), authored by the aforementioned educator from São Paulo, was made, taking as a point of analysis a comment contained on page 12 of the preface made by researcher Carlos Monarcha, from UNESP, about the priest's resistance, hampering the progress of Ceará's reform. , beginning the second stage. The crossing of such readings, allowed a mapping and an outline of the historical territory where that ideological duel was fought, in a cultural context totic: urban versus rural. It is admitted that the expansion of the understanding of this issue, in the light of the set of the appropriate readings, is opportune to reflect the project of reform of the primary education, whose public school should have been offered to the masses, in that historical scenario of the Ceará education, above the ideological and religious interests and beliefs.
\end{abstract}

Keywords: Education; Remodeling; Resistance; School register.

\section{Resumen}

Esta investigación es de carácter cualitativo, de carácter bibliográfico, con un enfoque en la práctica de la investigación en historia de la educación, según los lineamientos sugeridos por Luca (2020). El punto de partida es un enfrentamiento que se produjo en el transcurso de la reforma escolar de Ceará, a principios de la década de 1920, que involucró al educador Lourenço Filho (1897-1970 y al Padre Cícero Romão (1844-1934). Responde al Registro Escolar. El desarrollo de lo estudio se realizó en dos etapas: en la primera, se realizó la lectura analítica de la obra Juazeiro do Padre Cícero (2002), de la citada educadora paulista, tomando como punto de análisis un comentario contenido sobre página 12 del prefacio realizado por el investigador Carlos Monarcha, de la UNESP, sobre la resistencia del sacerdote que obstaculiza el avance de la reforma de Ceará., iniciando la segunda etapa. El cruce de tales lecturas permitió un mapeo 
y un delineamiento del territorio histórico donde Se libró un duelo ideológico, en un contexto cultural dico tótico: urbano versus rural. Se admite que la ampliación del entendimiento de esta cuestión, a la luz del conjunto de lecturas oportunas, es oportuna para reflejar el proyecto de reforma de la educación primaria, cuya escuela pública debió haber sido ofrecida a las masas, en ese histórico es cenário de la educación cearense, por encima de los intereses y creencias ideológicos y religiosos.

Palabras clave: Educación; Remodelación; Resistencia; Registro escola.

\section{Introdução}

O presente estudo é de cunho qualitativa, de natureza bibliográfica, com enfoque na prática da pesquisa em história da educação, conforme as orientações sugeridas por Luca (2020). Inserto no campo da história da educação, tomou por ponto de partida um comentário exposto pelo pesquisador Carlos Monarcha, da UNESP, no prefácio do livro Juazeiro do Padre Cicero (2002, p. 12)), de autoria do educador paulista Lourenço Filho (1897-1970), dando conta do negacionismo pedagógico do religioso popular cearense Padre Cícero, então prefeito da cidade de Juazeiro do Norte, em não colaborar com as informações solicitadas pelo cadastro escolar, necessárias à reforma do ensino primário público, no começo da década de 1920 no Ceará.

$\mathrm{Na}$ tentativa de comprrender as razões que motivaram o referido sacerdote a tomar aquela decisão, de não prestar informações ao cadastro do governo sobre a situação escolar de seu município, o referido educador se dirigiu, em comitiva, até a micro região do Cariri, parte sul do território cearense, distante da capital Fortaleza $580 \mathrm{~km}$, onde se localiza aquela cidade. $\mathrm{O}$ relato da travessia litoral-sertão, com sua riquezas de detalhes geográficos e interpretações culturais complexas estão descrita na citada narrativa, constituindo-se uma fonte preciosa para se compreender as influências das correntes epistemológicas de orientação do debate em torno da dicotomia atraso X civilização, de um país rural frente a um novo contorno de outro Brasil que se desenhava pela força da industrialização e da urbanização, onde ganhava fôlego a defesa da escola primária pública e universal.

Partindo-se da questão suscitada por Monarcha, a leitura integral do referido livro foi tomada para análise, na medida em que as questões expostas na narrativa foram sendo cruzadas com ideias em outras leituras, na tentativa de acrescentar ao debate alguns olhares que permitam situar aquele embate ideológico no seu tempo, tendo de um lado uma proposta de reforma educaciona liberal, encarnada na figura de Lourenço Filho e, de outro, o conservadorismo clerical do padre Cícero, mesmo suspenso das ordens sacerdotais, fiel à Santa Sé, no combate às ideias seculares entendidas como ameças à dominação da Igreja católica.

Há, portanto, a expectativa de que a exposição proposta possa contribuir com uma ampliação do entendimento dessa questão, no cenário histórico da educação cearense, levando em consideração que ambos agentes sociais estivessem, cada um a seu modo, convencidos de estarem fazendo a coisa certa pelo bem do povo, sem que houvesse uma trégua para um encontro fortuito capaz de celebrar um entendimento de que a educação pública a ser ofertada para as massas, naquele período estivesse acima dos interesses e das convicções ideológica e religiosoas.

\section{Relações entre Estado e Igreja Católica no Brasil}

As relações estreitas, porém, nem sempre amistosas entre a Igreja Católica Romana, e o poder real em Portugal, deixaram herança nos destinos políticos do Brasil. As duas instituições, tanto o Estado Português, quanto a Igreja, estavam incumbidas pela organização e pela ordem do processo colonial brasileiro.

Ao Estado estava reservada a garantia da hegemonia do reino nos domínios de Além-Mar, por meio de uma política econômica e do povoamento da terra, conforme o pacto colonial. À Igreja Católica estava reservada a missão da educação dos filhos dos colonos e dos nativos. Para estes, tinha-se em vista a conversão ao catolicismo, ação encarada como o "controle das almas". Já para os primeiros, tinha-se a garantia da obediência ao Estado português. (Fausto, 2001, p.29).

Segundo Saviani (2008, p. 31), a Companhia de Jesus, do início da nossa colonização até meados do século XVIII, 
deteve nas mãos os destinos da educação no reino e na colônia, portanto, por mais de três séculos. Mas, durante o reinado de D. José I (1750-1777), com a nomeação de Sebastião José de Carvalho e Mello, o Marquês de Pombal (1699-1782), para o Ministério dos Negócios Estrangeiros e da Guerra, houve a expulsão dos jesuítas do reino e dos domínios lusitanos, em uma sentença assinada em 12 de janeiro de 1759, na qual pesava a acusação de crime de lesa-majestade.

Tal fato na agenda pombalina fora o prenúncio de transformações liberais em Portugal. Assim, o Estado português colocava em curso o intento de restringir o poderio da Igreja Católica, fortalecendo a tese de consolidação do Regalismo e amplificando a do Padroado. Isso resultou na transformação do clero secular nos ambientes coloniais, numa extensão da administração do reino. Cabe destacar que, segundo Castro (2001, p. 323), por meio do Padroado, os religiosos passavam a receber salários pagos pelo erário, como membros integrantes da burocracia do governo.

Em tal ambiente de renovação política e religiosa, o Estado português, segundo Santirocchi (2013, p. 03), caracterizado por uma tendência centralizadora, fortalecia o poder temporal e cerceava o poder espiritual, controlando a liberdade eclesial. Segundo Castro (2001, p. 323), com a revitalização de uma legislação regalista, de caráter doutrinário, o padroado régio dava totais poderes ao rei para intervenção na instituição religiosa católica em Portugal e nos seus domínios.

Com a independência política em 1822, o Império brasileiro deu continuidade à política regalista, adotando inclusive a instituição do padroado régio. O Imperador ocupava a função de um censor, que segundo Cury (1984, p. 14), analisava e avaliava os atos emanados da Santa Sé e decidia a viabilidade ou não de sua aplicação, caracterizando a Igreja Católica como sendo obra do próprio governo imperial.

Pelo fato de as estruturas fundamentais do catolicismo brasileiro não terem sido alteradas com o Império, sobretudo pela subordinação do poder eclesiástico ao poder temporal do imperador, a instituição religiosa foi aos poucos, de acordo com Souza (2013, p. 130), ganhando um caráter nacional, por ser enquadrada como um departamento da burocracia do governo. Padres seculares continuaram a receber côngruas do erário.

Há uma herança religiosa católica na organização política brasileira desde o início do processo da nossa colonização, que perdurou até ao advento da República que fortemente influenciou os processos educacionais. Afinal, segundo Cury (1984, p. 13), por mais de quatro séculos, o catolicismo figurou como a religião oficial do Estado.

No âmbito global, a Era do Liberalismo havia produzido seus frutos. $\mathrm{O}$ fermento lançado em forma de palavras atiçara os ânimos da sociedade civil europeia, ávida por mudanças radicais. Diversos países, dos menores estados europeus ao majestoso império britânico, de acordo com Shelley (2018, p. 384), foram avidamente sacudidos pelas reivindicações do momento, tais como, participação política, direito ao voto e liberdade de expressão, as quais desafiavam a ordem estabelecida.

O liberalismo propunha destruir, finalmente, as amarras que prendiam as sociedades europeias à tradição religiosa e ao poder da autoridade espiritual sem legitimidade histórica e política. Tal retórica foi endereçada ao clero romano. Era necessário recusar a assistência da Igreja Católica Romana. Segundo os principais ideólogos do liberalismo, a Santa Sé não tinha qualquer direito de conduzir a moralidade da vida política moderna. A política devia ficar independente da ética cristã.

Naquele ambiente de hostilidade era demarcada a crise do catolicismo romano. A aplicação da narrativa liberal, nos mais diversos setores da sociedade, punha em xeque a ortodoxia medieval. Assim, a Santa Sé, buscou fortalecer a compreensão tomista da relação da razão e da fé, sem se desviar dos ares provenientes da sociedade capitalista moderna, procurando chamar a atenção dos fiéis para o que denominou de "barbárie civilizada", ao tempo em que enaltecia os valores espirituais católicos. (Cury, 1984, p. 12). A referida instituição religiosa se lançou, conforme Villaça (2006, p. 92), numa nova cruzada em defesa do fortalecimento da doutrina da Igreja, da tradição religiosa e da autoridade papal, contra o homo liberalis, encarnado no "maçonismo" e no secularismo.

Desconfiando do uso da ideologia do progresso material observado na sociedade industrial do século XIX como ferramenta para abalar a fé cristã, o papa Pio IX, por meio do documento Syllabus Errorum, de 1864, versando sobre os males 
da época, e o papa Leão XIII, com a publicação da Encíclica Rerum Novarum, de 1891, versando sobre a disparidade entre o trabalho e o capital, a refletir os direitos e deveres de empresários para com os trabalhadores, chamavam a atenção dos cristãos para as ilusões apontadas pela ideologia do liberalismo. Admitiram que o conjunto de transformações da sociedade industrial exigia uma abordagem à luz das teses tridentinas. Com isso, defenderam intransigentemente a manutenção da tradição, conforme Shelley (2018, p. 389), no intuito de fortalecer o movimento ultramontano, entendido como a retomada da obediência absoluta ao Pontífice de Roma, prevista na tese da "infalibilidade do papa".

A Cúria romana viria a demonstrar algumas reservas em assumir pacto com o ideário que nutria algumas premissas do mundo moderno, principalmente no tocante à ideia de progresso associado com a laicização do estado, bem como do liberalismo econômico. Por isso procurou fortalecer a autoridade máxima do papa, como chefe da Igreja, sobretudo conclamando os bispos a assumirem esta nova cruzada contra os desregramentos da civilização moderna.

Em 08 de dezembro de 1864, o papa Pio IX (1846-1878) publicava a Encíclica Quanta Cura, contendo em anexo o documento Syllabus ${ }^{l}$, no qual estavam impressos os "demônios" da sociedade moderna, a serem combatidos pela igreja de Roma: o liberalismo, socialismo, o racionalismo, a liberdade de imprensa, a liberdade religiosa, as escolas públicas e, principalmente, a separação da Igreja com o Estado. (Shelley, 2018, p.390). Apesar disso, Leão XIII, no final do século XIX deu alguns passos em direção ao mundo moderno, numa tentativa de diálogo da igreja com as forças liberais. O melhor exemplo disso foi a publicação da Encíclica Rerum Novarum, de 1891.2

Com a proclamação República no Brasil, segue para o exílio a Família Imperial, e, ao cair a Monarquia brasileira, também se abalava o poder da Igreja Católica no Brasil., Em vista disso, por meio da Ordem de Cristo e do Poder Moderador, o Imperador D. Pedro II, por mais de quatro décadas, fora o único homem com o poder pessoal de representatividade da nação brasileira e do poder espiritual católico, como sentinela absoluto a observar, a preservar valores cristãos e a intervir nos desígnios da política brasileira. (Caldeira, 2017, p.302).

A Constituição republicana de 1891 instituiu a separação do Estado e da Igreja Católica, pondo fim ao padroado régio, bem como estabelecendo a instituição de registros e casamento civis, a liberdade de culto e a secularização dos cemitérios. Ao ser retirado da esfera da religião, o Estado brasileiro se separou da Igreja. Como resistência eclesiástica, os padres seculares tiveram que conviver com a nova ordem política, De acordo com Caldeira (2017, p. 309), agora fora da sombra do guarda-sol do novo Estado brasileiro, a Igreja tinha que sobreviver às suas próprias custas.

\section{Os Desdobramentos Educacionais na Formação Sacerdotal do Padre Cicero Romão}

Nas derivações das reformas da Igreja Católica empreendida pela Cúria Romana em meados do século XIX, o Papa Pio IX (1792-1878), por intermédio da bula Pró Animarum Salute ${ }^{3}$, em seis de junho de 1854, cria o bispado do Ceará, por desmembramento do de Pernambuco. Por conseguinte, conforme o que estabelecera o padroado, o Imperador D. Pedro II, por meio do Decreto Imperial de 27 de janeiro de 1855, nomeou o primeiro bispo da Província do Ceará, D. Luíz Antônio dos Santos (1817-1891). Este viria a dar encaminhamento aos projetos atrelados ao Ultramontanismo.

O bispo tinha urgência na organização de um centro de formação de novos padres, de acordo com as exigências da nova reforma daquela instituição eclesiástica. Um seminário episcopal foi o instrumento necessário a uma adequada formação de uma elite intelectual capaz de conduzir espiritualmente os rebanhos cearenses, de acordo com os cânones da Santa Sé. (Parente, 2004, p.81).

Em âmbito nacional, o bispado iniciou sua empreitada reformista em duas vertentes: a primeira, purgação de párocos

\footnotetext{
${ }^{1}$ Syllabus Errorum. Disponível em: http://www.montfort.org.br/bra/documentos/enciclicas/silabo/

${ }^{2}$ Rerum Novarum. Disponível em: http://www.montfort.org.br/bra/documentos/enciclicas/silabo/ .

${ }^{3}$ Pro animarum Salute. Disponível em: http://www.montfort.org.br/bra/documentos/enciclicas/silabo/
} 
em atuação no território brasileiro, por meio da exigência da unidade cristã, da pureza da doutrina e pelo redirecionamento da religiosidade popular, condenando qualquer rito que se afastasse dos cânones da Santa Sé, ao mesmo tempo em que deveria privilegiar a ortodoxia católica na orientação dos fiéis. A segunda, a preparação de um adequado ambiente educacional, nos novos moldes de uma formação romanizada, ou seja, de acordo com a obediência a Roma, capaz de formar novas lideranças religiosas. (Azzi, 1992, p.33).

No embalo do processo de romanização da igreja Católica no Ceará, D. Luiz Antônio dos Santos anunciou à comunidade, por intermédio da publicação da Lei 1.144, de 27 de setembro de 1860, a criação do Seminário Episcopal na capital, soerguido num elevado do bairro Outeiro da Prainha, o qual iniciou suas atividades pedagógicas e espirituais em 18 de outubro de 1964.

A educação dos futuros padres do Seminário Episcopal foi entregue aos cuidados pedagógicos e espirituais da Ordem da Congregação da Missão, os filhos de São Vicente, chamados padres lazaristas, de origem francesa. Acreditava o bispo, também formado sob a orientação dos padres de referida ordem, que os futuros clérigos, uma vez bem preparados nos moldes da política eclesial renovada, sob o fortalecimento dos valores tracionais da fé católica romana, seriam capazes de resistir à onda de secularização da sociedade ocidental, ou seja, a fazer frente às chamadas ideias seculares, quer o liberalismo, o panteísmo, o evolucionismo, dentre outras.

A finalidade pedagógica da formação dos seminaristas confinados em seminários deveria ser um espelho a refletir lampejos de uma tradicionalidade capaz de se contrapor a este crescente movimento secular da modernidade.

O primeiro reitor do Seminário Episcopal, nomeado pelo bispo, foi o Padre Pierre Auguste Chevalier (1864-1891). A ele coube a organização educacional do seminário cearense, conforme as orientações ultramontanas. Ai, a organização dos estudos compreendia dois cursos: o preparatorista, com duração de seis anos e o Teológico, com duração de quatro anos. As disciplinas obrigatórias para o curso de Teologia eram as seguintes: Direito Canônico, História Eclesiástica, Moral, Dogma e Hermenêutica.

Aquele ambiente do Seminário aguardava a matrícula do jovem seminarista Cícero Romão Batista. Ele fez parte da primeira turma, composta por 12 jovens. Foi ordenado em 30 de novembro de 1870. Dali saiu sacerdote, com uma bagagem educacional e religiosa que cumpria todo o protocolo episcopal priorizado pela orientação da igreja de Roma. Segundo Della Cava (1976, p. 32), ao retornar à cidade do Crato, onde nascera, logo viria a se aproximar da comunidade de Juazeiro, onde se tornaria líder espiritual dos sertanejos nordestinos e desvalidos de toda sorte.

\section{Os Liberais, a Educação Pública e a Atuação de Lourenço Filho}

Não é novidade destacar que o governo imperial brasileiro negligenciou a educação nacional. Segundo Marcílio (2016, p. 231), a escola pública passou despercebida pelas autoridades provinciais, pelo Ministério do Império, que cuidava da pasta, e, principalmente, pelo governo central.

Mesmo existindo uma Lei Geral do Ensino que, datada de 15 de outubro de 1827, complementando o Art.179, inciso XXXI da Constituição de 1824, garantia a gratuidade da instrução primária a todos os cidadãos do Império. No entanto, a educação pública, por todo o século XIX, seria ofertada em conta gotas, à mercê do parco erário das províncias e da boa vontade política.

No Brasil do século XIX, a efetiva montagem de um sistema nacional de ensino e o enfrentamento do analfabetismo da população escolar, bem como a universalização e gratuidade da educação primária e da oferta do ensino secundário pela esfera pública, fora adiada para o século seguinte. Destacam-se, a partir da segunda metade do século XIX, alguns esforços políticos em defesa da escola pública, embora fossem reformas de ensino restritas à cidade do Rio de Janeiro e servissem de modelo às demais províncias para, a partir dele, se orientarem na condução de suas escolas.

A República herdou do Império baixos indicadores educacionais que envergonhavam o país frente da Europa, dos 
Estados Unidos, e de países do próprio continente sul americano, como, por exemplo, a Argentina. O Brasil era um país com uma população estimada em $80 \%$ a $90 \%$ de analfabetos absolutos. Os indicadores educacionais refletiam o modelo de sociedade constituído em total discrepância com um modelo social de economia aberta, uma vez que o processo de acumulação estava arraigado na grande propriedade rural, na monocultura e na mão de obra escrava, conforme pode ser verificada na tese exposta por Caio Pardo Jr. (2012).

Nesse contexto, como a educação brasileira poderia ter um índice de avaliação positivo se as forças históricas, arraigadas na tradição, a impediam? Se a educação elementar pública, laica e gratuita é apontada como uma conquista das sociedades democráticas do século XIX, tem-se que admitir que o Brasil atravessou quase todo o século XIX sob a égide de um estado absolutista, com uma economia não liberalizada, cujo imperador, por meio do Poder Moderador, controlava e decidia as pautas políticas de interesse nacional.

Com esses dados é possível entender a reação intelectual do começo da década de 1920, pois com 65,3\% da população maior de 15 anos de idade, analfabeta, conforme Marcílio, (2016, p.245), o país foi sacudido por uma onda de movimentos intelectuais em defesa da escola pública. Dentre os grupos de pensadores da educação, havia defensores de vertentes educacionais opostas, porém o ponto crucial era ensejado pelo debate sobre o direito de ficar na responsabilidade pela escola elementar.

Encontravam-se aí os de orientação liberal, influenciados pela filosofia educacional do pensador norte-americano John Dewey (1859-1952), principal referência do movimento escolanovista no Brasil, e aqueles de orientação católica, a partir das matrizes doutrinárias da Quanta Cura, referenciada anteriormente, e da Encíclica Rerum Novarum, da mesma forma citada, que reafirmavam a doutrina da Igreja Católica.

Tal período foi rico em debate sobre o papel da escola e da responsabilidade política pela educação porque os liberais, em sua maioria defensores de um projeto publicista de educação, mesmo contando com parcelas resistências dentro da própria ala, foram protagonistas das principais reformas do ensino primário nos estados brasileiros, como tentativa de ruptura com os determinantes educacionais deixados pela política do Império. Tanto que, da proclamação da República até o final da década de 1920, a sociedade brasileira gritava por ajustes políticos e sociais que fossem capazes de incluir parcelas da população sem escolaridade.

No referido contexto social e econômico, uma nova configuração da sociedade representava o esforço na direção do progresso. $\mathrm{O}$ crescimento da população, associado à urbanização e à industrialização, sinalizava mudanças na nossa economia, movidas pela substituição de importações, após o fim da $1^{\text {a }}$ Guerra Mundial, conjugada com uma política de incentivo à imigração estrangeira.

Nesse contexto, cabe destacar a cidade de São Paulo como centro irradiador do capitalismo moderno no Brasil. Era o principal centro industrial do país, ancorando seu processo industrial na indústria têxtil, fortalecida pela presença da mão de obra estrangeira, principalmente, de cidades italianas (Schwarcz \& Starling, 2015, p.335).

Da cidade de São Paulo, na década de 1920, brotaram os movimentos intelectuais que buscaram refletir os desígnios da cultura e da política nacional no contexto da República Nova. O movimento cultural chamado Modernismo teve como expressão a Semana de Arte Moderna de 1922, no Teatro Municipal da cidade, provocando discussões e gerando rupturas no campo da estética, com a finalidade de criação de uma cultura nacional. Segundo Nogueira (2001, p. 75), o movimento modernista repercutiria, além do campo literário, artístico e cultural, também no campo educacional. Neste âmbito, segundo Nagle (2001), destacou-se o movimento da Escola Nova, composto pelos "profissionais do ensino", divididos entre entusiastas e otimistas pedagógicos trazendo uma nova narrativa educacional de orientação liberal, arraigada nas ideias do pensador norte americano John Dewey. Integrados na Associação Brasileira de Educação $(\mathrm{ABE})^{4}$, os profissionais do ensino passaram a exigir dos governos

\footnotetext{
${ }^{4}$ A Associação Brasileira de Educação - ABE foi criada em 1924 por iniciativa de um grupo de 13 intelectuais identificados com o chamado movimento Escola Nova. (SAVIANI, 2008, p.229). Era uma entidade representativa das ideias novas do ensino, composta por um grupo de
} 
estaduais uma decisão política capaz de aniquilar o analfabetismo na população em idade escolar no território nacional. Segundo Saviani (2008, p. 177), as primeiras décadas do século XX foram caracterizadas pelas ideias que advogavam o direito universal do processo de escolarização das massas, por meio da ação do Estado.

Nesse cenário político nacional, dois grupos se digladiavam no campo das ideias em torno da defesa de um amplo projeto de educação. O grupo da ABE, liderado por Fernando de Azevedo (1894-1974), Anísio Teixeira (1900-1971) e Lourenço Filho (1897-1970), que promoveu a defesa da escola pública, laica e gratuita, dentro da abordagem temática das Conferências Nacionais de Educação. No outro extremo, o grupo dos católicos, concentrados no Centro D. Vital, liderado pelo cardeal D. Sebastião Leme (1882-1942), criador da revista Ordem, Jackson de Figueiredo (1891-1928) e Alceu Amoroso Lima (18931983), que se lançaram na defesa da permanência dos princípios da doutrina cristã na educação nacional.

Numa síntese de algumas ideias apontadas pelo trabalho desenvolvido por Cury (1984), liberais e católicos debatem no referido contexto temas embasados na defesa da educação elementar, ao perceberem-se como participantes de um suposto mundo em crise. Para os liberais, tratava-se de uma crise pautada em duas causas cruciais: uma se ligava ao espírito científico do tempo, e a outra se voltava para a análise da inadaptabilidade dos sujeitos à realidade da sociedade em movimento. Para os católicos, a crise do mundo ocidental tinha seu endereço no afastamento do ser humano em relação a sua natureza e ao seu criador, devido aos avanços materiais da sociedade moderna.

Se o grupo liberal enaltecia o avanço da ciência, da técnica e da sociedade industrial, rumo ao progresso da humanidade, os católicos enxergavam isso como condução do ser humano a um suicídio moral, por facilitar uma autonomia política do indivíduo frente à autoridade divina e à Igreja. Tais máximas se chocavam com os aforismos liberais porque estes admitiam a racionalidade, a experimentação e o cuidado com os fatos gerados na supremacia da vitória humana sobre os enigmas da natureza. A sociedade nascida da revolução científica e tecnológica propunha novos modelos econômicos, que facilitavam a divisão social do trabalho e produziam as relações democráticas entre os indivíduos em sociedade.

No tocante à educação, os liberais viam a escola como um instrumento capaz de integrar as gerações às novas demandas de uma sociedade em processo. Para isso, um projeto amplo de educação popular teria que levar em consideração a abertura de escolas e a garantia de matrícula para todos os indivíduos.

Sem ignorar o debate, os profissionais do ensino levaram adiante o ciclo de reformas que o ensino primário exigia, na década de 1920. Assim foram, conforme destacou Saviani (2008, p. 177) Sampaio Dória, em São Paulo em 1920; Lourenço Filho, 1920 no Ceará; Lysímaco Ferreira Costa e Prieto Martinez, no Paraná, em 1923; José Augusto, no Rio Grande do Norte, em 1924; Anísio Teixeira, na Bahia, em 1925; e também, de acordo com Nogueira (2001, p. 101), Antônio Prado Junior e Fernando de Azevedo, no Distrito Federal, em 1925; Carneiro Leão, em Pernambuco, em 1928.

\section{O Prefeito de Juazeiro do Norte não Responde o Cadastro Escolar}

As reformas educacionais desencadeadas na década de 1920, pelos profissionais do ensino nacional vinculados à ABE, foram melhor elaboradas porque continham uma orientação científica que privilegiava o método de ensino, o serviço de estatística, a criação de livros didáticos, e a formação e capacitação de professores.

No início da década de 1920, o governador Justiniano de Serpa (1920-1923), sob recomendação do Diretor da Escola Normal, o médico João Hipólito de Azevedo e Sá (1881-1962), nomeou o educador paulista Manuel Bergström Lourenço Filho (1897-1970) para conduzir a reforma da educação primária no Ceará.

professores e, principalmente, pensadores da educação capazes de mobilizar a opinião pública pela imprensa sobre a necessidade de renovação e publicização da escola. Como entidade representante dos intelectuais reformadores, passou a promover inúmeras atividades para reunir pessoas e acalorar o debate com ideias em torno de um projeto democrático de educação nacional, por meio de Conferências de Educação. (MARCILIO,2005, p.143). 
Dados extraídos do Almanaque do Ceará (1920, p.64) apontam que, à época, a população cearense estava estimada em 1.400.000 habitantes. No tocante à educação, o ensino era supervisionado pela Inspetoria Geral da Instrução Pública, cuja realidade do ensino nos 86 municípios, de então, no estado, era descrita da seguinte maneira: na capital havia seis grupos escolares e 52 escolas isoladas. Nos demais municípios, somavam-se 476 escolas primárias.

A chegada do educador Lourenço Filho a Fortaleza foi em 14 de abril de 1922. Com tal presença, setores progressistas da sociedade nutriam a esperança de transformação da realidade educacional cearense. Aquele profissional seria capaz de conduzir a reforma, neutralizando as forças conservadoras que, de alguma maneira, controlavam as nomeações nas secretarias de governo, por meio de práticas fisiológicas e nepotistas.

Com o apoio logístico dado pelo governo estadual, Lourenço Filho foi nomeado para a Diretoria Geral da Instrução Pública, além de ser efetivado no cargo de professor da Escola Normal para as cadeiras vagas de Psicologia e Pedagogia.

O governo cearense sabia que não teria êxito na reforma educacional sem o apoio das lideranças políticas locais. Para isso, tratou logo de organizar na capital do estado, em junho de 1922, o Congresso de Prefeitos e Chefes Políticos, reunindo em torno de $90 \%$ dos representantes municipais. Durante o evento, muitas questões da política local foram debatidas, inclusive a sucessão ao executivo e as disputas ao legislativo. Mas o foco do evento foi a apresentação das diretrizes gerais da reforma educacional, com a proposta de um questionário com 62 perguntas para compor o cadastro escolar. Vale ressaltar que, conforme Pinho (2004, p. 44), mesmo diante da importância do congresso, o município de Juazeiro do Norte não se fez presente e nem nomeou representante ao evento.

Conforme aprovado na plenária do congresso, os municípios, segundo o que previa a constituição do estado, deviam garantir os meios necessários para custeio da referida ação. Segundo Nogueira (2001, p. 143), custeariam as despesas com materiais e de transporte do funcionário recenseador, assim denominado Inspetor Regional.

À frente da Diretoria Geral de Instrução, os trabalhos de Lourenço Filho começaram com a publicação do Regulamento da Instrução Pública (Lei 1.953). Em seguida, fez-se a divisão dos 86 municípios cearenses em seis regiões censitárias, com a nomeação, para cada região, de um inspetor regional a coordenar o recenseamento escolar. O trabalho consistia em visitar cada uma das cidades de sua competência para coletar in locus os dados sobre número de escolas, quantidade de matrículas, professores, material didático-pedagógico, acesso à escola, permanência de alunos na escola, dentre outros. Ao concluírem as visitas, cada inspetor deveria produzir um relatório parcial para ser enviado àquela diretoria, na pretensão de fazer um mapeamento estatístico da situação socioeconômica e educacional do estado.

No curso da reforma, a Diretoria Geral de Instrução criaria a Escola Modelo, na própria instituição escolar que Lourenço Filho ministrava aula. Ressalta-se como motivo de comprometimento com o projeto, a participação do governador Justiniano de Serpa em uma dessas aulas.

Dentro do projeto da Escola Modelo, eram propostos cursos de férias aos docentes da capital e do interior, no ambiente interno do teatro José de Alencar. O objetivo era o treinamento e a capacitação em serviço, tendo em vista a introdução dos métodos de ensino propostos pela pedagogia moderna. Nessas conferências, o referido professor aproveitava também para palestrar sobre higiene escolar, tendo em vista ter sido criado nas escolas da capital o serviço médico-escolar.

Segundo informação levantada por Newton Craveiro (1893-1926), um dos inspetores gerais responsáveis pela elaboração do livro didático João Pergunta ou o Brasil seco (1923), que se tornou leitura oficial nas escolas públicas cearenses, Lourenço Filho permaneceu em terra alencarina por apenas vinte meses. Porém, foi o tempo necessário para tocar a reforma do ensino no Ceará. As alterações começaram pela reorganização da Escola Normal, sem rupturas com seu currículo humanista, mas suprimindo cadeiras consideradas desnecessárias e criando novas, como a de Pedagogia e a de Psicologia Experimental. A

${ }^{5}$ Almanaque estatístico, administrativo, mercantil e comercial do Ceará. (1920). Fortaleza: Tipografia Moderna, pp 64-67. 
inclusão dessas cadeiras caracteriza uma tentativa político-pedagógica de orientação curricular científica.

Em seguida, destaca-se a necessidade de ser feito um levantamento de informação sequenciada referente à realidade educacional do estado. Para isso, o ponto de partida era o cadastro escolar, algo que já havia sido utilizado na reforma de São Paulo. O cadastro escolar daria um balanço geral da realidade do ensino cearense, a partir de quatro eixos: 1) Recenseamento de todas as crianças de 6 a 12 anos que fossem analfabetas ou não; 2) Inscrição de auxílios das prefeituras ou particulares para criação de prédios escolares; 3) Balanço do material existente nas escolas públicas (inventários), e a organização estatística geral do ensino; 4) Uma enquete com os chefes de famílias sobre horários e férias escolares; dentre outras questões locais.

Com maestria, o educador Lourenço Filho procurou não criar atrito com os setores do clero cearense. Por meio de um ofício, enviado ao arcebispo D. Manuel da Silva Gomes (1874-1950), pediu o apoio da diocese de Fortaleza para empreender aquela reforma de instrução pública. Nesse documento, demonstrou respeito à religião católica, reconhecendo a idoneidade moral da instituição religiosa, embora a Constituição Federal primasse pelo Estado leigo. Na finalização do documento, o autor devota a importância da função da Igreja Católica na orientação das crianças. Era a abertura que o clero cearense precisava para propor a inserção do ensino religioso na escola primária pública.

No entanto, as ideias reformistas encontraram resistência nos domínios territoriais de Padre Cícero. Sem representar oficialmente o clero, sobretudo por se encontrar suspenso de ordens, desde o fenômeno conhecido por "milagre em Juazeiro", acusado de embuste, (Della Cava, 1976), o padre Cicero se tornou uma poderosa liderança religiosa e política na região sul do Ceará. Participou como vice do governo de Nogueira Accioly na gestão de 1904-1912, e era o responsável pelo levante de 1914, chamado de "Sedição de Juazeiro" (Girâo,1984, pp.193-198), que contribuiu para a renúncia de Marcos Franco Rabelo (19121914) no governo do Ceará6.

Lourenço Filho, que já havia entrado em acordo com as lideranças religiosas oficiais do Ceará, por meio do ofício supracitado, não viu nenhum problema em ir tratar diretamente com o Padre Cícero lá na cidade de Juazeiro do Norte. Preparou, então, uma comitiva e, varando o sertão da braba caatinga, a bordo de um automóvel, chegou à cidade de Juazeiro do Norte.

O espanto gerado pelo primeiro olhar do educador paulista sobre aquele microcosmo social, de casas e ruas povoadas por uma massa sertaneja orientada pela fé, trabalho e penitência, em estado de obediência e adoração à figura do Padre Cícero, sustentaria às máximas da estereotipia do referido educador com relação ao sertão brasileiro, de que ali a civilização ainda não havia chegado. Juazeiro do Norte, concluiria, era o elo a um passado medieval.

Profundamente influenciado pela produção literária e sociológica de cunho naturalista-realista do começo do século XX, de lançar o olhar sobre o sertão fiel à descrição do meio, seguindo o parâmetro deixado por Euclides da Cunha em $O s$ Sertões, as notas de viagem de Lourenço Filho na travessia do sertão cearense, partindo do litoral, em direção à "Meca dos Sertões"7, segundo Albuquerque Júnior (2009, p. 73), serviram de esteio para algumas reportagens publicadas pelo jornal Estado de São Paulo, o que mais tarde daria origem ao livro Juazeiro de Padre Cícero.

O encontro da comitiva de Lourenço Filho com o Padre Cícero se deu de forma aprazível. Embora tendo usado todo o poder de persuasão de que dispunha para explicar ao reverendo a importância do cadastro escolar, nada conseguiu fazer com que o padre Cícero mudasse de ideia em relação à recusa dos esclarecimentos pretendidos. Os membros do governo voltariam para Fortaleza sem nenhuma informação documental oficial da cidade.

\footnotetext{
${ }^{6}$ Sob a ameaça de uma coluna de jagunços sertanejos armados que descia do Cariri em direção à sede do governo na capital Fortaleza, o governo eleito Franco Rabelo preferiu renunciar ao executivo cearense e embarcar em um vapor que navegava em direção à capital da República, cidade do Rio de Janeiro em janeiro de 1914.

${ }^{7}$ Termo usado por Lourenço Filho, no citado livro (p.31), faz uma alusão à mística que a cidade de Juazeiro do Norte desperta ao olhar do educador paulista, visitante daquele universo social. Um "cenário tocado por superstições" (p.33), arraigado numa prática ritual de um cristianismo sertanejo, nutrido pela veneração dos peregrinos à figura do Padre Cícero.
} 


\section{À guisa de uma conclusão}

Difícil avaliar a materialidade da reforma Lourenço Filho em números que permitam enxergar os avanços da educação primária, com destaque para construção de escolas e aumento de matrículas e permanência de alunos pobres no ambiente escolar do sertão do Ceará. Os indicadores educacionais da reformar demonstram uma concentração de ações mais restritas ao ambiente educacional de Fortaleza.

Complexo é, também, pelo manuseio de fontes tendenciosas, censurar a postura do Padre Cícero em não colaborar com o cadastro escolar, no momento em que o governo precisava compor um estudo sobre a realidade educacional de cada município. Vale destacar que ambos os sujeitos históricos, Lourenço Filho e o Padre Cícero, naquele contexto, representavam os pólos ideológicos de uma querela que, em nível nacional, vinha se arrastando na arena política e educacional, desde a segunda metade do século XIX, em prol da responsabilidade pela educação primária para os pobres no Brasil.

Com o desdobramento da pretendida reforma educacional no Ceará, Juazeiro do Norte sediaria uma conversa entre o liberal e educador paulista Lourenço Filho e o cearense Padre Cícero, de formação ultramontana, avesso ao liberalismo, que girou em torno de um convencimento para que o município prestasse as informações devidas ao governo estadual, mas de fato não aconteceu.

Frustrado com a decisão radical do Padre Cícero, em não responder o cadastro escolar, as notas de viagem daquela visita deram origem ao livro Juazeiro do Padre Cícero, publicado na cidade de São Paulo, em 1926. O livro constitui uma fonte descritiva do sertão cearense, mesmo que pese sobre as elucubrações as influências epistemológicas da época, arraiga e fundamentada em princípios eugenistas e higienistas.

Considerada sua obra de estreia nas letras nacionais, foi bem acolhida pela crítica literária da época, a ponto da Academia Brasileira de Letras elevá-la à categoria de "Ensaios", em 1927.

É perceptível que os fatos reportados na obra não a isentam da influência preconceituosa e intolerante que, em conformidade com o discurso médico, biológico e sociológico do começo do século XX, influenciava a plêiade intelectual brasileira. Pela leitura da obra, verifica-se a acidez do educador Lourenço Filho ao arrematar sobre o padre Cícero como um líder místico, a conduzir seu rebanho na linha tênue entre a prática de um fanatismo com ritos medievais, e a "insânia" sertaneja, que desautorizava incluí-lo no contexto ultramontanista.

Arremata-se, então, a comparação pejorativa, sob seu olhar de escritor, de Juazeiro do Norte a "uma zona fora da lei e da razão" (Lourenço Filho, 2002, p.34), que havia perdido o elo da história com o mundo civilizado, distanciando seus dias do progresso, e condenando-se ao fracasso cultural e mental.

Não obstante, Monarcha (2001, p. 21) reforçaria que o contato do educador Lourenço Filho com o padre Cícero, na cidade de Juazeiro do Norte, na primeira impressão do olhar de um paulista, causara impacto na sua mentalidade racional, de onde elaboraria uma imagem "ruinosa" e "desarrazoada" da figura do Padre Cícero, que ficaria registrado nas páginas do citado livro.

Entretanto, uma releitura mais compreensiva das fontes sobre aquele episódio no Ceará, também permite associar a atitude do padre Cícero, em não querer responder ao cadastro escolar como conservadora e refratária ao avanço da democratização do ensino público. E, ainda, como uma decisão, supostamente fiel à ortodoxia da Santa Sé, reflexo talvez da sua própria formação sacerdotal ultramontana, cuja finalidade era a formação de lideranças religiosas capazes de combater não apenas o chamado catolicismo sertanejo, mas, principalmente, as forças do progresso cientificista, traduzidas no combate ao liberalismo e ao protestantismo.

A atitude tomada pelo padre Cícero não impediu o curso dos trabalhos da reforma de ensino no Ceará. No entanto, seria ingenuidade histórica, supor que aquele sacerdote letrado no sertão nordestino, com a qualidade da formação sacerdotal que recebera no Seminário da Prainha, mesmo suspenso das ordens pelo Vaticano, estivesse alheio ao debate educacional moderno 
que circulava pela grande imprensa nacional, na década de 1920.

Trazer ao debate acadêmico uma reflexão sobre um fenômeno educacional ocorrido em um passado distante é sempre um desafio da pesquisa social, principalmente por se tratar de uma tentativa de aproximação das novas gerações às questões de um tempo que, de alguma maneira, interferiram no andamento da escola pública brasileira. Nesse sentido, tal estudo instiga futuras pesquisas que possam esclarecer os embates verificados nos percursos e nos itinerários das reformas educacionais empreendidas na década de 1920, sob a responsabilidade e expensa dos governos estaduais. Tais propostas de organização e efetivação do ensino primário nacional, embora trazendo ao cenário educacional o que havia de mais moderno no campo das ideias e das práticas pedagógicas, nem sempre foram bem entendidas e aceitas pelas elites conservadoras do nosso país, à frente do mandonismo político local e nacional.

\section{Referências}

Azzi, R. (1992). O Trono é Unido ao Altar: Um Projeto Conservador. Paulinas.

Caldeira, J. (2017). História da riqueza no Brasil. Cinco séculos de pessoas, costumes e governos. Estação Brasil.

Castro, Z. O. (2001). Antecedentes do Regalismo pombalino: O Padre José Clemente. In: Estudos em homenagem a João Francisco Marques. (Vol. VI), (pp. 232-231). Porto: Faculdade de Letras, da Universidade do Porto.

Cury, C. R. J. (1984). Ideologia e educação brasileira. Católicos e liberais. (2a ed.). Cortez/Autores Associados.

Cavalcante Neto, J. L. (2009). Padre Cícero - Poder, Fé e Guerra no Sertão. Cia das Letras.

Della Cava, R. (1976). O milagre em Juazeiro. Paz e terra.

Fausto, B. (2001). História Concisa do Brasil. Edusp.

Girão, R. (1984). Pequena história do Ceará. EdUFC.

Lourenço Filho, M. B. (2001). Juazeiro do Padre Cícero. (4a ed.), DF: INEP/MEC.

Luca, T. R. (2020). Práticas de pesquisa em História. Contexto.

Marcílio, M. L. (2016). História da alfabetização no Brasil. Ed USP.

Marcílio, M. L. (2005). História da escola em São Paulo e no Brasil. Imprensa Oficial de SP; Inst. Fernand Braudel.

Nagle, J. (2001. Educação e Sociedade na Primeira República. DP\&A.

Nogueira, R. F. S. A. (2001). prática pedagógica de Lourenço Filho no estado do Ceará. Edições UFC, 2001.

Parente, F. J. C. (2002). A fé e a razão na política: Conservadorismo e modernidade das elites cearenses. EDUFC.

Prado Jr. C. (2012). História econômica do Brasil. Brasiliense.

Priori, M. D. \& Venancio, R. (2016). Uma breve história do Brasil. (2a ed.). Planeta.

Santirocchi, I. D. (2013). Padroado e Regalismo no Brasil independente. In: XIV Jornadas Interescuelas/Departamentos de Historia. Departamento de Historia de la Facultad de Filosofía y Letras. Universidad Nacional de Cuyo, Mendoza.

Saviani, D. (2009). História das Ideias pedagógicas no Brasil. Autores Associados.

Schwarcz, L. M. \& Satarling, H. M. (2015). Brasil: uma biografia. Cia das Letras.

Shelley, B. L. (2018). História da Cristianismo: uma obra completa e atual sobre a trajetória da igreja cristã desde suas origens até o século XXI. Thomas Nelson Brasil.

Souza, N. (2013). Catolicismo, sociedade e teologia no Brasil Império. Revista Atualidade Teológica. Rio de Janeiro, 46,127-144. https://www.maxwell.vrac.puc-rio.br/23290/23290.PDFXXvmi=.

Villaça, A. C. (2006). O pensamento católico no Brasil. Civilização brasileira. 